\title{
Groundwater Quality Analysis in Nusakambangan Groundwater Basin/Indonesia
}

\author{
Thomas Triadi Putranto ${ }^{1,2 *}$, Adrian Hanenda Qadarisman ${ }^{1}$, Narulita Santi ${ }^{1}$, and Najib Najib ${ }^{1}$ \\ ${ }^{1}$ Geological Engineering Department, Engineering Faculty, Diponegoro University, Semarang - Indonesia \\ ${ }^{2}$ Master Program of Environmental Science, School of Postgraduate Studies, Diponegoro University, Semarang-Indonesia
}

\begin{abstract}
Nusakambangan groundwater basin is located in Nusakambangan Island, Cilacap Regency. Sea and swamp-bound the research area and there is no deep well, and the only one dug well available. This condition encourages the community to collect water from a pool of karst cave which unproven water quality. The study purpose is to determine the water feasibility at interest point as drinking water. The methods were hydrogeological field campaign by collecting 33 water sampling from pools and one sample from dug well to analyse physical and chemical properties as well as calculating the Water Quality Index (WQI). The results show the physical properties of water samples are having a relatively colourless but brownish in some samples, odourless, and a salty taste. The chemical properties indicated that the $\mathrm{pH}$ of water samples are ranging from 6,95 to 8,06 with the electrical conductivity (EC) start from 350 to $38,800 \mu \mathrm{S} / \mathrm{cm}$. Moreover, the Total Dissolved Solids (TDS) have a value from 216 to $21,800 \mathrm{mg} / \mathrm{L}$ with the total hardness is around $134-5,395 \mathrm{mg} / \mathrm{L}$. The water types are $\mathrm{Ca}-\mathrm{Mg}-\mathrm{HCO}_{3}$ and $\mathrm{Na}-\mathrm{Cl}$. Based on WQI analysis, there are 13 unfeasible samples for drinking water in the south-east of Klaces village, in the western of Ujunggalang village, and in the Eastern of Tambakreja village.
\end{abstract}

Keywords: Nusakambangan groundwater basin; chemical properties; Groundwater Quality Analysis; WQI

\section{Preliminary}

Groundwater Quality Analysis is the process to make in the present study to analyse the water quality parameters and to find the sea water intrusion. The water quality parameter comprises physical, chemical and biological characteristics.

The composition of groundwater is influenced by many processes, including wet and dry depositions of atmospheric salts, evapotranspiration, and water-soil and water-rock interactions. Many data concerning groundwater quality are required to identify groundwater masses. Advanced procedures must be applied because the complexities of the regional hydrogeological conditions and hydrochemical processes that occur in aquifers are difficult to be explained and documented. Hydrochemistry analysis can be applied to interpret relationships among variables, to yield more significant relationships that provide insight into the underlying structure of the variables, to assess controls on groundwater composition, and to evaluate the spatial distribution of the studied case.

Therefore, the water quality is essential to be fulfilled to secure our health. In Indonesia, the standard is the Regulation of Health Minister Indonesia (Permenkes) N0.492/MENKES/PER/IV/2010. The standard from the World Health Organization (WHO) which released in 2011 is a water quality standard on an international scale. In determining the feasibility of groundwater quality as drinking water, we need to do Water Quality Index analysis by counting and weighing at a particular chemical groundwater aspect [1] in Nusakambangan Groundwater Basin. This weighting is based on how much influence of one of the chemical property or ion content to the whole groundwater sample [2] and also what is the effect for human health.

The purpose of the research is to determine the chemical compound inside the groundwater at Nusakambangan Groundwater Basin, and also to determine the feasibility of water to be utilized as drinking water based on Water Quality Index analyze with World Health Organization (2010) and Regulation of Health Minister Indonesia (Permenkes) N0.492/MENKES/PER/IV/2010 [3] as an International and local drinking water quality standards. The sustainable of groundwater management will potentially contribute of multiples scopes of sustainable development especially for planning low carbon communities. Sustainable groundwater management can ensure climate-resilient supplies of water needed to provide goals for food security, energy development and water drinking access. It can contribute water for industrialisation and for sustainable cities.

Corresponding author: putranto@ft.undip.ac.id 


\section{Study Area}

The location of research belongs to the administrative area of Cilacap Regency with an area of $48.73 \mathrm{~km}^{2}$ (Fig.1). It is located in Nusakambangan Groundwater Basin at Nusakambangan Island.

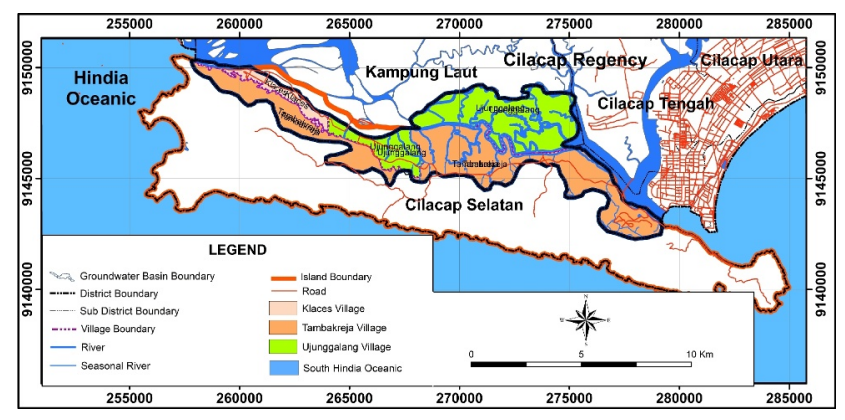

Fig. 1. Study Area.

\section{Research Method}

The methods were hydrogeological field campaign to collect 34 sample of water which consists of 33 pool samples and 1 dug well. The $\mathrm{pH}$ and electrical conductivity values were measured by $\mathrm{WtW}$ profile $\mathrm{pH}$ 3210 and Cond 3310 during the field campaign, respectively. The Indonesian Geological Agency laboratory analysed the chemical properties such as Total Hardness, $\mathrm{Na}^{+}, \mathrm{SO}_{4}{ }^{2-}, \mathrm{Cl}^{-}, \mathrm{NH}_{4}^{-}$, and $\mathrm{Fe}^{3+}$ to calculate the Water Quality Index.

\subsection{Hydrogeology Interpretation}

Figure 2 shows the regional hydrogeological setting of the groundwater basin. There are several types of aquifers in Nusakambangan Groundwater Basin. The first type of aquifer is aquifer with water flow through cracks, fractures, and channels. This aquifer can be composed by land and river alluvial plain, mainly by sand, gravel, silt, and clay. It has mid until high level of porosity and spread in the west to the east of Cilacap region. Next, there is an aquifer with low productivity which has a low level of porosity, local type, and the amount of groundwater is limited that obtained from valley area or weathered zone. This aquifer is composed of tuff sandstone, sandstone, conglomerate, tuff, breccia, and clay. The last aquifer is a rare groundwater area. It has a low of porosity value with the rare availability of groundwater, even in the rainy season.

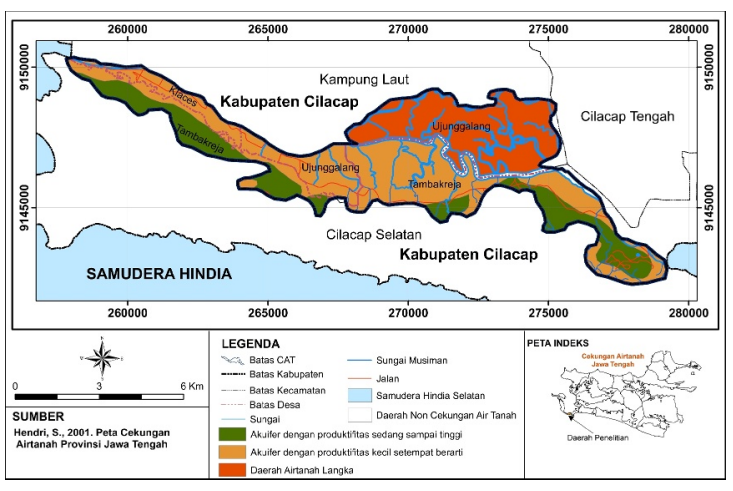

Fig. 2. Nusakambangan groundwater basin map [4]

\subsection{Groundwater Chemical Properties}

Groundwater chemical properties are acidity $(\mathrm{pH})$, electrical conductivity, total dissolved solids (TDS), and hardness. Acidity is a degree that states acid and basic compositions expressed by $\mathrm{pH}$ unit. The value of this property is affected by the composition of ions which create acidic and basic compound both from low to highs hydrogen content. Electrical conductivity is a property that affected by a chemical compound as well as a salt deposit which can conduct electricity at a specific temperature and expressed by $\mu \mathrm{S} / \mathrm{cm}$.

If water composed of salt in a large quantity, the water will have a high value of electrical conductivity [5]. It indicates that the value of electrical conductivity will be proportional to the value of TDS. TDS property itself is affected by the presence of salt-forming elements like Iron (Feron) which interpreted comes from the dissolution of volcanic rock. Hardness is a chemical property that affected by the composition of $\mathrm{Ca}^{2+}$ dan $\mathrm{Mg}^{2+}$ ions. These ions will form solid salt compounds with $\mathrm{HCO}^{3-}, \mathrm{Cl}^{-}$, and $\mathrm{SO}_{4}{ }^{2-}$ as anions. Groundwater has $\mathrm{K}^{+}, \mathrm{Na}^{+}, \mathrm{Mg}^{2+}$, dan $\mathrm{Ca}^{2+}$ ion as the major cations and $\mathrm{Cl}^{-}$, $\mathrm{HCO}_{3}{ }^{-}$, dan $\mathrm{SO}_{4}{ }^{2-}$ ion as the major anions.

\subsection{Groundwater Quality Analysis with WQI}

In Indonesia, the drinking water standard is appointed by the Regulation of Indonesian Ministry of Health (Permenkes) N0.492/MENKES/PER/IV/2010. The standard from the World Health Organization (WHO) which released in 2011 is a water quality standard on the international scale [8]. In determining the feasibility of groundwater quality as drinking water, we need to calculate Water Quality Index analysis by counting and weighing at a specific chemical groundwater aspect [1] in Nusakambangan Groundwater Basin. This weighting is based on how much influence of one of the chemical properties or ions content to all groundwater samples [2] and also determining the effect for the human health. The parameter determination and weighting is certainly 
relative and doesn't have any of reference as each of the water analysed has the degree of influence of hydrochemical parameters varying from one region to another.

On this groundwater quality research evaluation, the influence parameters evaluated based on the water drinking quality standard by using WHO (2011) standard in international scale[3]. After we got the value of Wi from a result of weighting (Eq. 3.1), the next step is to calculate the qi by comparing the parameter value $(\mathrm{Ci})$ with equivalent standard value ( $\mathrm{Si}$ ) then times 100, (Eq. 3.2). Moreover, adding the value of Wi and qi to conduct the subindex value (SI) from each of parameter as shown in Eq. (3.3). After resulted in the SI value from all parameters, then the WQI value can be obtained by the sum in total all the SI from each parameter (Eq. 3.4). The value of WQI will be classified into the WQI classification using the both WHO and Permenkes standards, to determine whether the value classifies as very good water or unfeasible water.

Table 1 Chemical parameter for WQI analysis

\begin{tabular}{|c|c|c|}
\hline \multirow{2}{*}{$\begin{array}{l}\text { Chemical } \\
\text { Parameter } \\
(\mathrm{mg} / \mathrm{L})\end{array}$} & \multicolumn{2}{|c|}{ Limit } \\
\hline & $\begin{array}{l}\text { WHO } \\
2011\end{array}$ & $\begin{array}{l}\text { No.492/ } \\
\text { ENKES } \\
\text { PER/IV } \\
10\end{array}$ \\
\hline TDS & 1,000 & 500 \\
\hline Hardness & 500 & 500 \\
\hline $\mathbf{N a}^{+}$ & & 200 \\
\hline $\mathrm{SO}_{4}{ }^{2-}$ & 250 & 250 \\
\hline $\mathrm{Cl}^{-}$ & 300 & 250 \\
\hline $\mathrm{NH}_{4}^{-}$ & 2 & 1.5 \\
\hline $\mathrm{Fe}^{3+}$ & 0.3 & 0.3 \\
\hline & & $w i$ \\
\hline & & $\overline{\sum_{i=1}^{n} w i}$ \\
\hline & & $<100$ \\
\hline & $S I$ & Vi $\times q i$ \\
\hline & $W($ & $\sum S I$ \\
\hline
\end{tabular}

\section{Results and Discussion}

\subsection{Geological of Research Area}

Based on the result of field observation, the research area consists of various lithology. The most dominant lithology that exposes on the surface is alluvial. Indeed, three are the type of rocks the which are sedimentary carbonate rocks such as limestone, and clastic sedimentary rocks, i.e. interbedded sandstone with claystone, and fragmental igneous rock as tuff with sand inserts. The distribution of the lithology is shown on Nusakambangan lithology distribution Map (Figure 3).

\subsection{Hydrogeology Condition}

The groundwater level of collecting pool considered to be same as the elevation of the collecting pool location. Then, the only dug well that found, has a groundwater level at 51.3 meters. Figure 4 shows the water table and its direction. Groundwater flows from the southeast to the northwest.

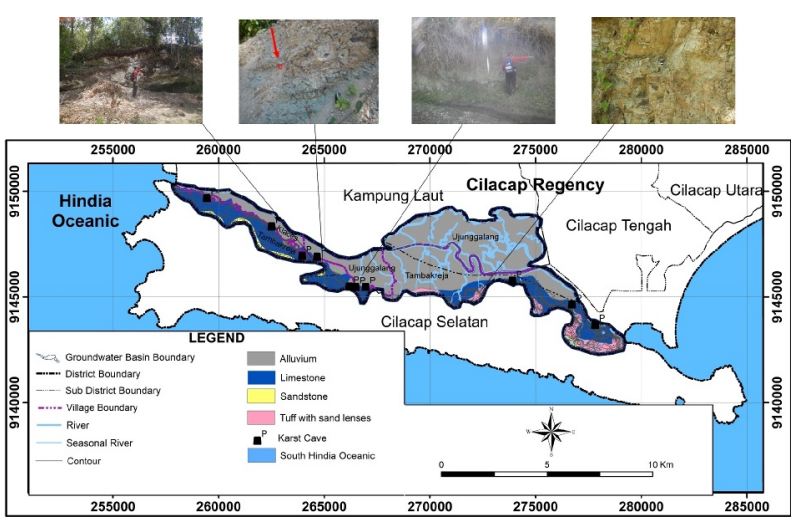

Fig. 3. Nusakambangan lithology distribution Map

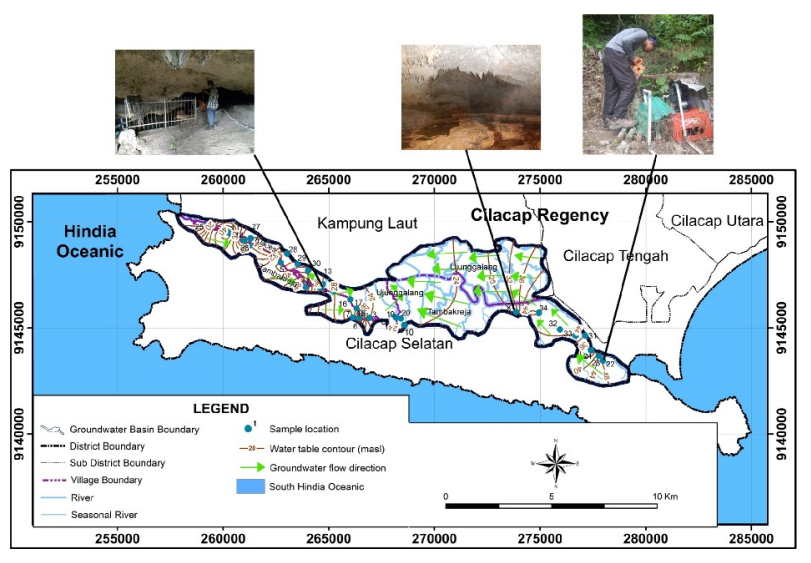

Fig 4. Water table and its flow direction. Left and middle photos showing measuring water table in the collecting pool area while the right photo showing measuring water table in the dug well.

\subsection{Groundwater Chemistry}

The hydrochemical parameters which analysed are $\mathrm{pH}$, electrical conductivity, hardness, and Total Dissolved Solids (TDS)[12]. While the physical properties which 
analysed are colour, smell, and groundwater muddiness level [10].

Based on the laboratory analysis, the acidity $(\mathrm{pH})$ is around 6.95-8.06. This value shows that the chemical property of the water dominantly is neutral to the base. Figure 5 shows the distribution of acidity in the research area.

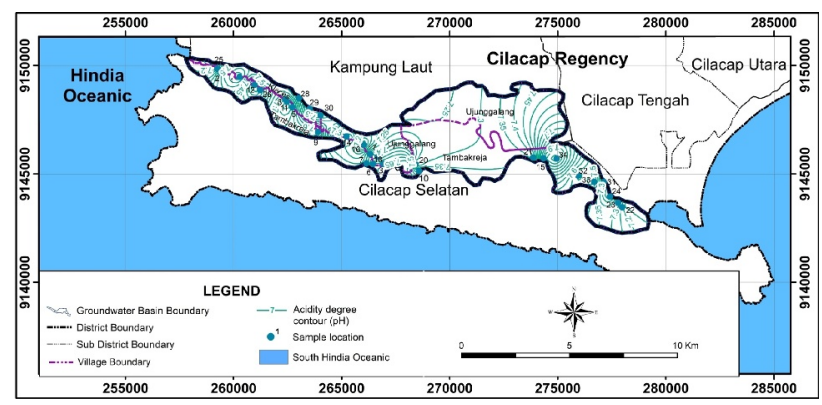

Fig. 5. Distribution of acidity $(\mathrm{pH})$ of Nusakambangan groundwater basin

The electrical conductivity (EC) values have a range from 350 to $38,800 \mu \mathrm{S} / \mathrm{cm}$. Based on the water type classification using EC value [5], twenty-one samples are freshwater while the rest indicate seawater.

The locations with the high electrical conductivity values are dominantly at Klaces Village, whole Tambakreja Village and a part of northern Ujunggalang Village. Figure 6 shows the contour line that created by the interpolation of the electrical conductivity data. Based on this map, it shows that the EC value is higher to the north than in the south.

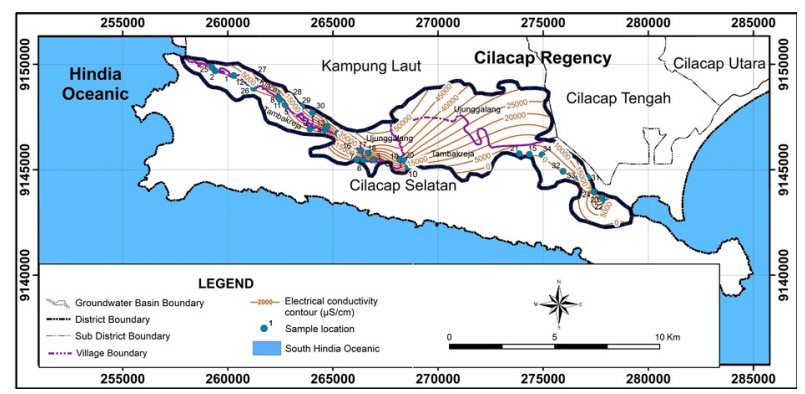

Fig. 6. Distribution of electrical conductivity value

Meanwhile, the Total Dissolved Solids (TDS) the has a range of $216-21,800 \mathrm{mg} / \mathrm{L}$ [7]. There are 21 samples of fresh water, and 13 are very salty water. It is highly recommended to determine the type of water by the TDS value [6]. Based on TDS map, the TDS contour will be higher to the north. It tends to be the same as the electrical conductivity map which proves that electrical conductivity value is proportional to TDS value on every point of samples (Figure 7).

The total hardness shows that 34 samples have total hardness values at around 133.6-5,395 mg/L [7]. The dominant cations are $\mathrm{Ca}^{2+}$ and $\mathrm{Mg}^{2+}$. [9]. Thus, based on the total hardness classification, there is 1 sample as medium water, 19 samples as hard water, dan the rest as very hard water. Water from the karst cave has high total hardness value. It is distributed in Tambakreja Village. Based on Figure 8, it shows that the total hardness contours have a higher value to the north.

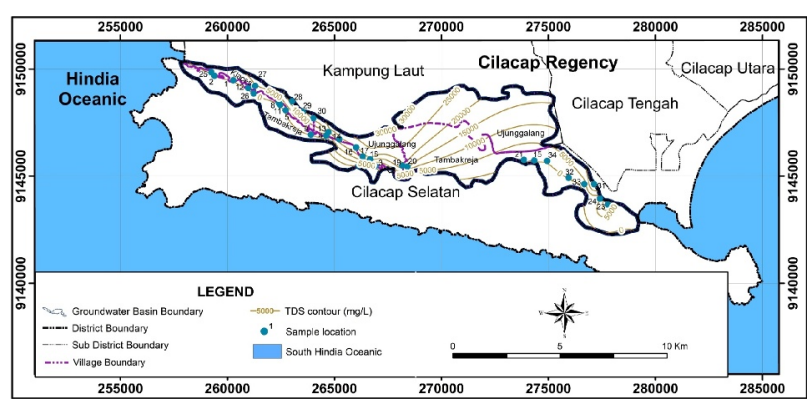

Fig. 7. Distribution of Total Dissolved Solids (TDS)

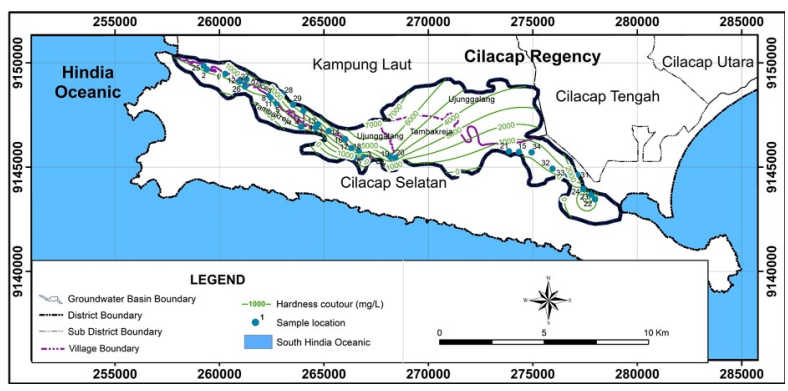

Fig. 8. Distribution of Hardness of Nusakambangan groundwater basin

\subsection{Groundwater Quality Analysis using WQI}

The water samples have been tested on the chemical content to conducted the WQI Index. When calculating using WHO (2011) standard [8], the WQI values result around 11.9-2,111. Figure 9 shows the distribution of Water Quality Index (WQI) based on WHO standard. After conducted the WQI Index on each point of water sample [13], the WQI value is classified the using the WQI classification scale. Table 2 shows that 13 samples 
are classified as unfeasible to drink while the rests are very good.

Table 2 WQI classification based on WHO 2011 standard.[8]

\begin{tabular}{llll}
\hline WQI Scale & $\begin{array}{l}\text { Qualit } \\
\text { y }\end{array}$ & $\begin{array}{l}\text { Percentage } \\
(\boldsymbol{\%})\end{array}$ & $\begin{array}{l}\text { Sample } \\
\text { Number }\end{array}$ \\
\hline$<50$ & $\begin{array}{l}\text { Very } \\
\text { Good }\end{array}$ & 62.8 & $\begin{array}{l}1-12,15,21- \\
22,24-26,32-\end{array}$ \\
& & & 34 \\
$50-100$ & Good & - & - \\
$100-200$ & Bad & - & - \\
$200-300$ & Very & - & - \\
$>300$ & $\begin{array}{l}\text { Bad } \\
\text { Unfeas }\end{array}$ & 37.2 & $13-14,16-20$, \\
& $\begin{array}{l}\text { ible to } \\
\text { drink }\end{array}$ & & $23,27-31$ \\
& & & \\
\hline
\end{tabular}

Meanwhile, the WQI Index calculation using the Regulation of Indonesian Ministry of Health (2010) result that the WQI values are around 16.2-2.718. Table 3 shows there are 13 samples have unfeasible to drink quality and requires special treatment to dissolve the hard salt on the water before it can be consumed [11], and two samples have a good quality. The distribution of point of interest with the drinking quality based on Regulation of Health Minister Indonesia can be pictured in Figure 10.

\section{Conclusion}

Based on analysis of Water Quality Index (WQI) to determine the feasibility to drink, it can be known that WHO (2011) standard and Regulation of Indonesian Ministry of Health No.492/MENKES/PER/IV/2010 resulted that 13 samples are classified as unfeasible to drink which located on southeast part of Klaces Village, west part of Ujunggalang Village, and east part of Tambakreja Village. The rests are very good and good quality.

Table 3 WQI classification based on the Regulation Indonesian Ministry of Health No.492/MENKES/PER/IV/2010.

\begin{tabular}{llll}
\hline $\begin{array}{l}\text { WQI } \\
\text { Scale }\end{array}$ & Quality & $\begin{array}{l}\text { Percent } \\
\text { age }(\%)\end{array}$ & $\begin{array}{l}\text { Sample } \\
\text { Number }\end{array}$ \\
\hline$<50$ & Very Good & 55.9 & $\begin{array}{l}1-11,15,21-22, \\
24-26,33-34\end{array}$ \\
$50-100$ & Good & 6.88 & 12 and 32 \\
$100-200$ & Bad & - & - \\
$200-300$ & Very Bad & - & - \\
$>300$ & $\begin{array}{l}\text { Unfeasible } \\
\text { to drink }\end{array}$ & 37.2 & $13-14,16-20$, \\
& & $23,27-31$ \\
\hline
\end{tabular}

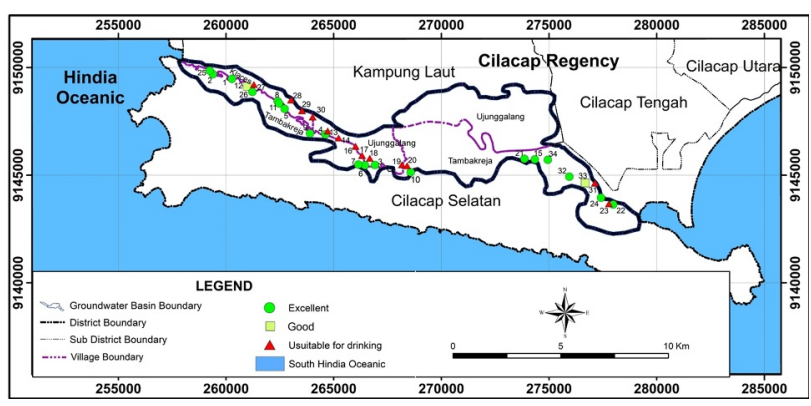

Fig. 9. Groundwater quality map with WQI using WHO standard

\section{Acknowledgement}

The authors thank the Geological Engineering Department, Faculty of Engineering in Diponegoro University for the research funding in the scheme 'Hibah Bersaing ' the contract number 2687/UN7.3.3/PG/2018.

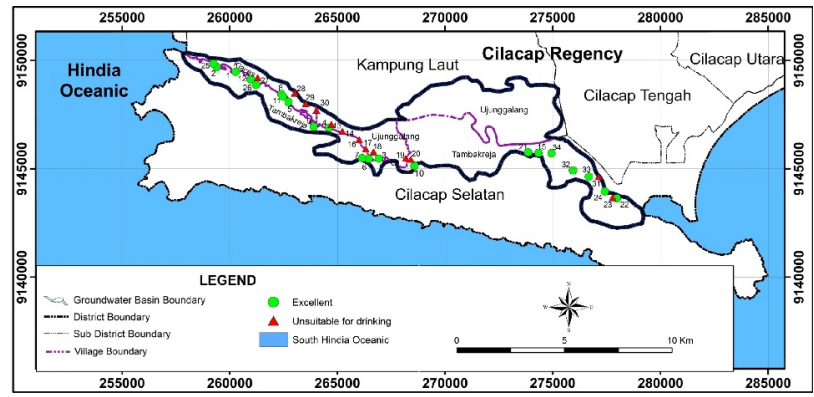

Fig. 10. Groundwater quality map with WQI based on the Regulation of the Indonesian Ministry of Health

\section{References}

1. Al-hadithi, M. American Journal of Scientific and Industrial Research, ISSN: 2153649X,doi:10.5251/ajsir.2012.3.6.395.402. (2012)

2. Ponsadailakshmi, S., Sankari, S.G., Prasanna, S.M., Madhurumbal, G., Journal Elsevier: Groundwater for Sustainable Development 6 (2018)

3. Permenkes. Peraturan Menteri Kesehatan NOMOR 492/MENKES/PER/IV/2010 Tentang Persyaratan Kualitas Air Minum. (2010)

4. Hendri, S. Peta Cekungan Airtanah Propinsi Jawa Tengah, Semarang: Kerjasama Dinas Pertambangan dan Energi Propinsi Jawa Tengah dengan Direktorat 
Tata Lingkungan Geologi dan Kawasan Pertambangan, Skala 1:100.000. (2001)

5. Todd, D.K., Groundwater Hydrology, New York, United State of America: Wiley (1980)

6. Ebrahimia, M., Kazemia, H., Ehtashemib, M., Rockaway, T.D.,Journal Elsevier: Chemie der Erde 76. (2016)

7. Gaman, M., Ilmu Pangan, Pengantar Ilmu Pangan, Nutrisi, dan Mikrobiologi, Edisi II, Yogyakarta: Gadjah Mada University Press (1992)

8. WHO. Guideline for Drinking-Water Quality, Fourth Edition, ISBN 979 924. 154815 1, WHO Library Catalouging in Publicating Data (2011)

9. Ahmed, A., Clark. Groundwater flow and geochemical evolution in the Central Flinders
Ranges, South Australia, Elsevier: Science of the Total Environment 572 (2016)

10. Liu, F., Songa, X., Yang, L., Han, D., Zhan, Y., Ma, Y., Bua, H., Elsevier: Science of the Total Environment 538 (2015)

11. Priya, K.L., Jebastina N., Prince A.G., Scientific report Journal 1: 186, doi:10.4172/scientificreports.186 (2012)

12. Yang, Q., Wang, L., Ma, H., Yu, K., Martín, J.D. Journal Elsevier: Environmental Pollution 216 (2016),

13. Ramakrishnaiah, C.R., Sadashivaiah, C., dan Ranganna, G. E-Journal of Chemistry, ISSN: 09734945 (2008) 